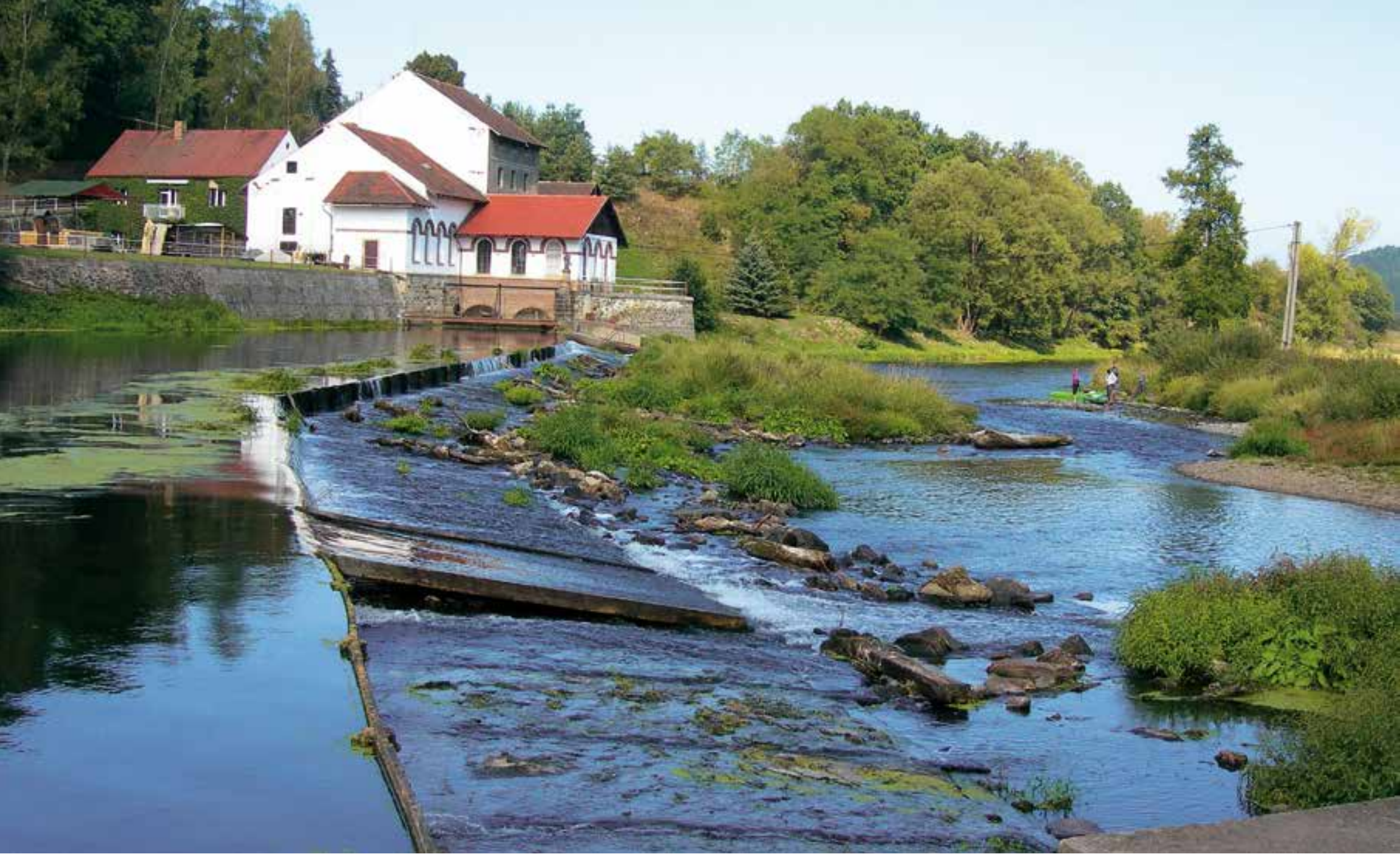

\title{
Návrh obsahu plánu pro zvládání sucha a nedostatku vody $v$ ČR
}

\section{RADEK VLNAS}

Klíčová slova: sucho - nedostatek vody - vodní zdroje - plán

\section{SOUHRN}

Příspěvek představuje prípravnou fázi návrhu obsahu plánu pro zvládání sucha a nedostatku vody $v$ ČR v procesu připomínkování. Plán je základní dokument ochrany před následky sucha. Slouží ke koordinaci činností v daném území v období sucha a nedostatku vody. Jedná se o souhrn popisu území z hlediska vodních zdrojů a systému zásobování vodou, organizačních a technických opatření, potřebných k odvrácení nebo zmírnění škod v oblasti základních lidských potřeb a majetku, hospodářské činnosti a životního prostředí souvisejících s nároky na vodu v období sucha.

\section{ÚVOD}

Z usnesení vlády ČR č. 620 ze dne 29. července 2015 k prrípravě realizace opatrení pro zmírnění negativních dopadů sucha a nedostatku vody vyplynul v souvislosti s prípravou Koncepce ochrany pred následky sucha pro území České republiky požadavek přípravy návrhu obsahu plánů, jejichž cílem je koordinace činností v období sucha a nedostatku vody.

Následující text představuje základní východiska pro tvorbu plánu pro zvládání sucha a nedostatku vody v ČR (dále jen plán). Plán by měl sloužit pořizovatelům a zhotovitelům při zadání a prípravě plánu především na úrovni kraje, ale také pro obce s rozšírenou působností. 


\section{ZÁKLADNÍ POJMY}

Suchem se rozumí hydrologické sucho jako výkyv hydrologického cyklu, který vzniká zejména v důsledku deficitu srážek a projevuje se poklesem průtoků ve vodních tocích a poklesem stavu podzemních vod.

Stavem sucha se rozumí míra nebezpečí sucha vázaná na směrodatné limity, jimiž jsou zejména průtoky ve vodních tocích, hladiny podzemních vod a stav srážek nebo kritické hodnoty jiného jevu uvedené v př́islušném plánu pro zvládání sucha.

Nedostatkem vody se rozumí dočasný stav s potenciálním dopadem na základní lidské potřeby, hospodářskou činnost a životní prostředí, kdy $\checkmark$ důsledku sucha požadavky na užívání vod převyšují dostupné zdroje vod, a proto je nezbytné omezovat hospodaření s vodou a prijímat další opatření.

Plán pro zvládání sucha a nedostatku vody je dokument, který je podkladem pro rozhodování komise pro zvládání sucha a nedostatku vody a vodoprávního úřadu o opatřeních ke zvládání sucha a nedostatku vody. Jeho hlavním cílem je návrh opatření k zajištění dostatku vody k pokrytí základních společenských potřeb, minimalizaci negativních dopadů sucha na vodní útvary a minimalizaci dopadů sucha a nedostatku vody na hospodářskou činnost.

Komise pro zvládání sucha (dále jen komise) je orgánem s rozhodovací pravomocí pro prijímání opatření při hrozbě vzniku nedostatku vody podle plánu.

\section{ORGÁNY PRO ZVLÁDÁNÍ SUCHA A NEDOSTATKU VODY}

Orgánem pro zvládání sucha a nedostatku vody je vodoprávní úřad a od jejího svolání do ukončení činnosti komise. Komise rozhoduje podle plánu o opatřeních, a to zejména podle ustanovení § 6 odst. 4, §59 odst. 4 a § 109 odst. 1. Komise jsou zřizovány na ústřední úrovni, úrovni krajů a fakultativně též na úrovni obcí s rozširrenou působností.

Předsedou komise je hejtman kraje. V komisi je zastoupen vodoprávní úrad, odbor krizového řizení, podniky Povodí, Český hydrometeorologický ústav Hasičský záchranný sbor, Krajská hygienická stanice, Policie ČR. Poradní hlas mají vodou zásobující organizace, správci vodních toků a významní odběratelé vody.

Pokud dojde k vyhlášení krizového stavu podle zvláštního zákona, je komise součástí orgánu krizového řizení.

\section{OPATŘENÍ PROTI NEDOSTATKU VODY}

Opatření proti nedostatku vody Ize přibližně rozdělit na opatření prípravná, realizovaná v období mimo sucho nebo prí hrozícím nedostatku vody, a na opatrení realizovaná v průběhu sucha a nedostatku vody.

1. Přípravná opatření a opatření príi nebezpečí nedostatku vody jsou:

a. stanovení limitů kategorií sucha,

b. stanovení limitů pro prijímání opatření při nedostatku vody,

c. příprava a aktualizace plánu,

d. vytváření a príprava záložních zdrojů vody,

e. príprava záložních (mobilních) úpraven vody,

f. zavádění technologií omezujících spotřebu vody, g. zavádění technologií ke zlepšení jakosti vypouštěné vody,

h. príprava a činnost předpovědní a hlásné služby,

i. př́prava on-line systému monitoringu aktuální spotřeby a požadavků na vodu,

j. organizační a technická príprava,

k. príprava účastníků ochrany před nedostatkem vody,

1. upozornění na výskyt sucha,

m. zahájení informační kampaně,

n. evidenční a dokumentační práce.

2. Opatření při nedostatku vody uvedené v chronologickém sledu v závislosti na intenzitě průběhu situace nedostatku vody jsou:

a. průběh informační kampaně,

b. omezení obecného nakládání s vodami podle $§ 6$ odst. 4 vodního zákona,

c. mimořádné manipulace na vodním díle podle $\$ 59$ odst. 4 vodního zákona,

d. využití technologií omezujicích spotřebu vody,

e. omezení odběrů s platným vodoprávním rozhodnutím podle § 109 odst. 4 vodního zákona,

f. opatření k zajištění náhradního odběru podle § 109 odst. 4 vodního zákona,

g. dočasné snižení minimálních zůstatkových průtoků,

h. dočasné snížení minimálních hladin podzemní vody,

i. dočasné úprava limitů pro jakost vypouštěných odpadních vod (snížení limitů čistíren, jejichž technologie to umožňuje, zvýšení limitů u podniků po vyčerpání ostatních prostředků k omezení spotřeby vody (recirkulace)),

j. Zabezpečení náhradních funkcí a služeb v území zasaženém nedostatkem vody.

Opatření k omezení dopadů sucha na vodárenství, průmysl a zemědělství jsou často v konfliktu s jakostí vody a s cíli ochrany prírody (např. snížení odtoků z nádrží pod minimální zůstatkové průtoky mưže spolu s vysokými teplotami vést ke zhoršení jakosti vody). 


\section{HODNOCENÍ SUCHA}

Velikost, intenzitu a délku trvání sucha z hlediska vodních zdrojů vyhodnocuje Český hydrometeorologický ústav ve spolupráci s podniky Povodí. Vodními zdroji se rozumí povrchové a podzemní vody podle ustanovení vodního zákona'. Český hydrometeorologický ústav provádí hodnocení sucha z hlediska srážek, evapotranspirační bilance, průtoku $\vee$ tocích, stavu podzemních vod, podniky Povodí hodnotí zásob vody v nádržích. Monitoring a vyhodnocení hydrometeorologických veličin probíhá v týdenním kroku podle schématu na obr. 1 .

$\checkmark$ prípadě dosažení silného, resp. mimořádného, sucha $v$ území ORP nebo kraje vydá ČHMÚ upozornění na výskyt sucha v povrchových nebo podzemních vodách územně př́slušnému vodoprávnímu úřadu. Výskyt silného sucha odpovídá stupni upozornění bdělost, mimořádné sucho odpovídá stupni upozornění pohotovost. Vydání upozornění na sucho je jedním z impulsů ke svolání komise, dalším je překročení místních směrodatných limitů uvedených v plánu. Vodoprávní úrad po zvážení aktuální situace a výhledu dalšího vývoje plnění požadavků na vodu rozhodne o svolání komise.

\section{HODNOCENÍ NEDOSTATKU VODY}

Vodoprávní úřad $v$ souladu s plánem a ve spolupráci se správcem povodí vyhodnotí, zda na základě ohlášeného stavu sucha nebo překročení místních směrodatných limitů uvedených $v$ plánu vzniká nedostatek vody na celém jeho území či jeho části, a navrhne svolání komise. Svoláním komise vzniká stav nedostatku vody.

Směrodatné limity jsou stanovovány podle schopnosti systému plnit požadavky uživatelů na vodu podle bilance reálného stavu vodních zdrojů v území a požadavků na vodu. Limitem v rámci jednoduchého systému zásobování může být např. stav konkrétního vodního zdroje (průtok, hladina podzemní vody, objem nádrže, ...), na druhé straně v rámci vodohospodářské soustavy její schopnost plnit požadavky na vodu především preferovaných uživatelů po stanovenou dobu.

Hierarchie uživatelů při plnění nároků na vodu v období nedostatku vody je navržena podle významu způsobu užití vody pro společnost následovně:

A. Skupina A-celostátně důležité provozy, vybrané průmyslové podniky (zejména s nepřetržitým provozem) a tepelné elektrárny, prvky kritické infrastruktury;

B. Skupina B - zásobování obyvatelstva pitnou vodou, významné průmyslové podniky a živočišná zemědělská prvovýroba²;

C. Skupina C - průmyslové podniky oblastního významu;

D. Skupina D - ostatní zemědělská prvovýroba;

\section{E. Skupina E - ostatní užívání vod.}

Přijímání opatření, při nichž dochází k omezení práv uživatelů vody s platným vodoprávním rozhodnutím, by mělo odpovídat této hierarchii.

Po vzniku stavu nedostatku vody je zahájena nebo pokračuje informační kampaň (veřejnost, uživatelé), jsou aktualizovány informace o potřebě vody významných uživatelů, zajištěn monitoring množství a jakosti vodních zdrojů, připravována technická a organizační opatření.

$\checkmark$ situaci, kdy se sucho projevuje napjatou bilancí při plnění nároků na odběry nebo pro zachování minimálních zůstatkových průtoků nebo minimálních hladin podzemní vody, je podle plánu především omezováno obecné nakládání s vodami, jsou zaváděna opatření predevším za účelem omezení spotřeby (technologická opatření na straně průmyslových uživatelů) a přerozdělování zásob vody, navrhovány mimořádné manipulace na vodních dílech, omezovány odběry méně významných uživatelů podle hierarchie dané plánem.

Při dalším poklesu vodních zdrojů může docházet k vzniku škod většího rozsahu nebo ohrožení životů a majetku $v$ důsledku nedostatku vody pro zásobování pitnou vodou, zajištění provozu krizové infrastruktury a významných podnikư. Podle plánu dále probíhají činnosti za účelem omezení spotřeby vody a přerozdělování zásob vody, dochází k omezování dalších uživatelů v rámci hierarchie, může být umožněno dočasné snížení minimálních zůstatkových průtoků, minimálních hladin podzemní vody nebo dojít k úpravě limitů jakosti vypouštěných odpadních vod.

\section{OBSAH PLÁNU}

Plán by měl obsahovat následující části: titulní list, úvodní část, věcnou část, organizační část, grafickou část a prílohy.

Plán pořizuje a průběžně aktualizuje pro své území v přenesené působnosti krajský úřad ve spolupráci s príslušnými správci povodí a Českým hydrometeorologickým ústavem. Plán může pořídit pro svůj správní obvod také obecní úřad obce s rozšířenou působností. Plán menších celků musí být v souladu s plánem vyššího stupně, soulad potvrzuje příslušný orgán ochrany před suchem.

Revize základní části se provádí při výrazných změnách s komentářem změn. Revize operativní části se provádí $1 \times$ ročně ověřením platnosti všech údajů plánu, zejména s ohledem na personální obsazení a telefonní spojení.

\section{Titulní list}

Titulní list by měl obsahovat název plánu, orgány pro zvládání sucha a jejich sídlo, zpracovatele plánu, datum zpracování, schvalující úřad a datum schválení, záznamy (nebo odkaz do textu) o aktualizaci, potvrzení souladu s plánem vyšší úrovně, príslušné související (geograficky, technicky z hlediska zásobování vodou související) orgány pro zvládání sucha.

\section{Úvodní část}

Úvodní část by měla obsahovat:

- pravidla pro aktualizace;

- použité symboly a zkratky;

- použité termíny a definice, vysvětlení pojmů (sucho, nedostatek vody, opatření ... - citace právních predpisů apod.);

- orgány pro zvládání sucha a nedostatku vody (citace právních předpisů apod.);

- popis hodnocení sucha (kdo vyhodnocuje, co, jak, kategorie sucha - formou odkazu...);

- statut orgánu pro zvládání sucha a nedostatku vody (úvodní ustanovení, činnost orgánu pro zvládání sucha a nedostatku vody, druhy komisí (složení pracovního štábu komise, poradního orgánu komise, skupiny evidenčních a dokumentačních prací), jejich kompetence, jednací rád, spolupráce komise s ostatními orgány, fyzickými a právnickými osobami, zabezpečení činnosti komise, závěrečné ustanovení);

- jmenné seznamy, adresya způsob spojení účastníků ochrany před nedostatkem vody a úkoly pro jednotlivé účastníky této ochrany, způsob komunikace. 
ČHMÚ

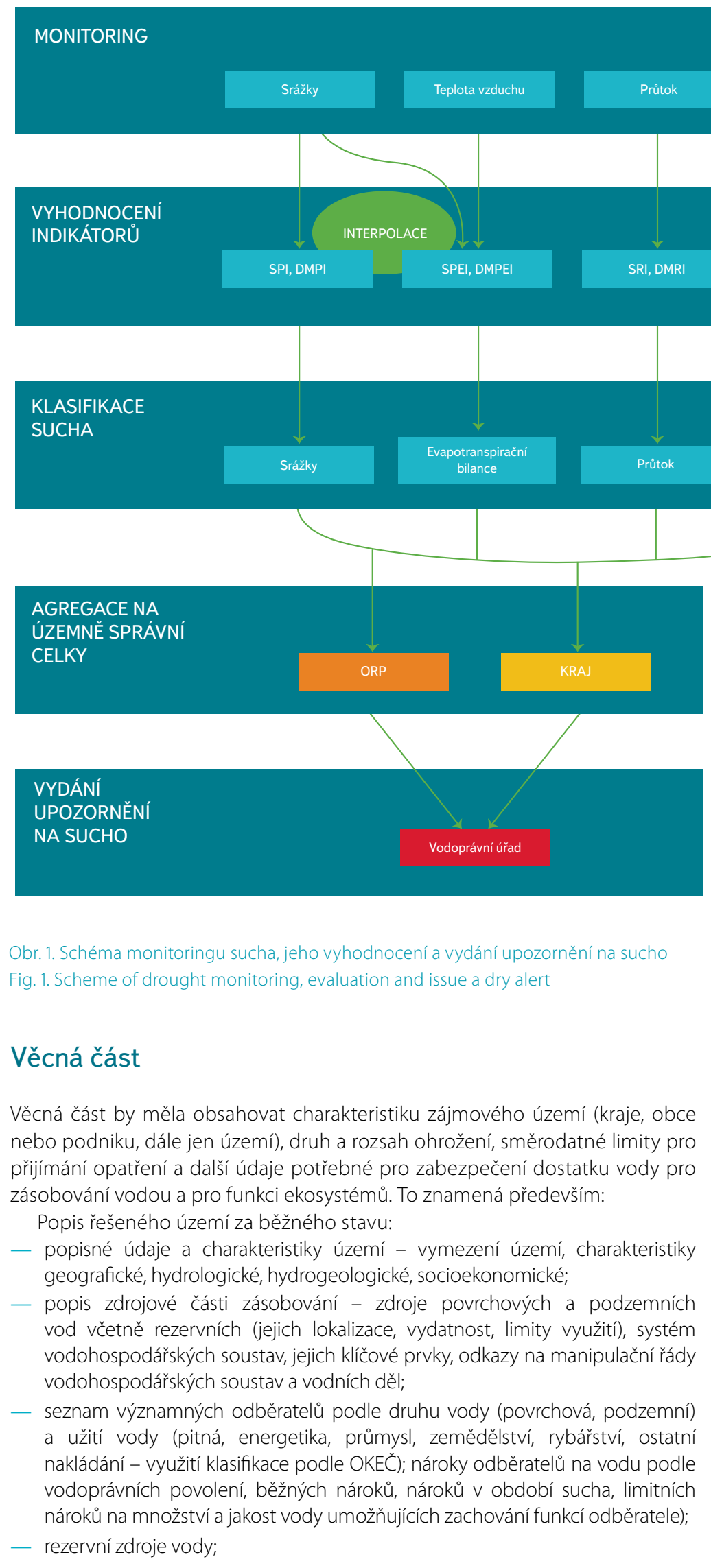

POVODÍ, s. p.
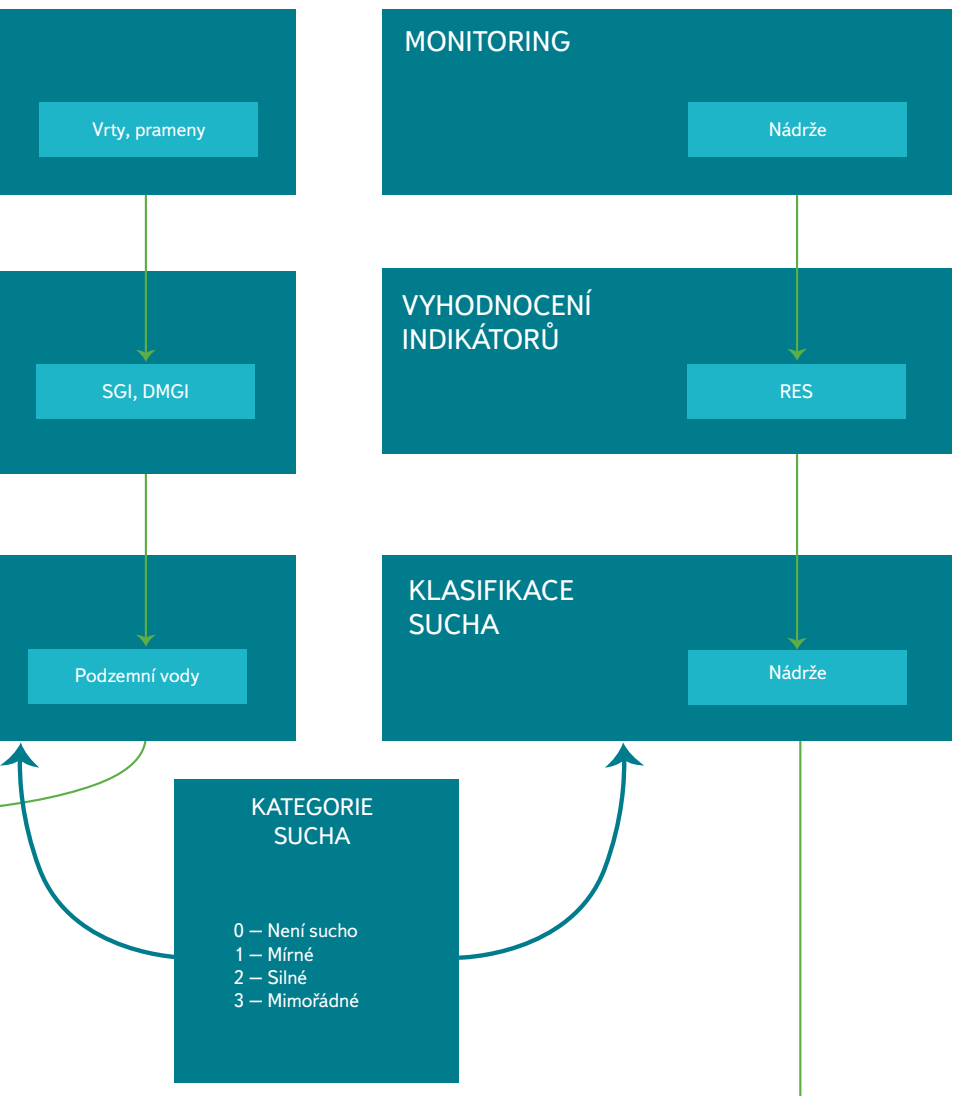

VYDÁNÍ

UPOZORNĚNÍ

NA SUCHO
- popis způsobu úpravy a dopravy vody a jeho prípadná propojenost a zastupitelnost:

- popis jakosti vody $v$ tocích, seznam hlavních znečištovatelů, jejich lokalizace a druh znečištění, vymezení za sucha citlivých úseků vodních toků;

- vyhodnocení proběhlých epizod sucha - jejich príčiny, projevy, postižené území, délka sucha, roční období, dopady na množství povrchové a podzemní vody, dopady na jakost vody, popis prijjatých opatření proti nedostatku vody a jejich účinnost;

- popis pravděpodobných rizik nedostatku vody v území - prííiny, postižení uživatelé vody druhu a užití vody, délka nedostatku vody, roční období, dopad na povrchové a podzemní vody, dopad na jakost vod, možné dopady nedostatku vody na životy a zdraví osob, na funkci kritické infrastruktury, ekonomické dopady, dopady na životní prostředí, na citlivé úseky toků pod zdroji znečištění, mezinárodní dopady.

Popis řešeného území v období sucha a nedostatku vody:

— seznam účastníků systému ochrany pred suchem (jejich povinnosti v operativní části); 
- popis rozhodujicích veličin (množství a jakost povrchové a podzemní vody), jejich monitoringu, zodpovědnost za monitoring (kdo provádí, jakým způsobem předává informace, odkazy na zdroje aktuálních informací);

- kritéria a místní směrodatné limity pro stanovení nedostatku vody;

- schéma toku informací výstražných informací ČHMÚ, informačních zpráv vodohospodářských dispečinků podniků Povodí, zpráv zásobujících organizací;

- postupy a prostředky (technická zařízení) pro snížení následků sucha a nedostatku vody - druh, způsob použití, místo uložení, majitel či správce.

\section{Organizační část}

Organizační část by měla obsahovat zejména:

- systém řešení sucha a nedostatku vody - druhy komisí, jejich složení, kompetence, vazby, jednací rád, způsob komunikace;

- obecné principy pro (včetně uvedení zodpovědné organizace, popř. osoby):

- zjištění provozního stavu zdrojových a přepravních systémů (existující poruchy, opravy, omezení),

- zjištění rozsahu deficitu a dopadů (počet obyvatel, zdravotnictví, sociální služby, bezpečnost, ostatní služby, socioekonomické dopady, životní prostředí),

— zajištění kontroly situace prímo v terénu,

— Četnější monitoring množství a jakosti vody,

— prognózy vývoje,

- priority zásobování,

- prijjatá opatření,

— realizace opatření,

— kontrola realizace opatření,

— modifikace opatření na základě dalšího vývoje situace,

- doporučené činnosti a opatření při fázích sucha pro jednotlivé účastníky procesu zvládání sucha.

— kompetence účastníků ochrany před nedostatkem vody;

— krajský úřad: zajištění činnosti komise, kontrola opatření, předávání informací,

— vodoprávní úřad: kontrola opatření (omezení odběrů apod.) v povodí týkajících se vodních toků a vodních děl (obecné nakládání s povrchovými vodami, nakládání s vodami v prípadech nezajištujuících prioritní zásobování vodou) ve spolupráci se správci povodí a správci vodních toků,

- ČHMÚ: monitoring aktuálního stavu povrchových a podzemních vod vývoje meteorologické situace, prognóza meteorologická a hydrologická,

— správci povodí: stav nádrží a prognóza jeho vývoje, kontrola nakládání s vodami, sledování jakosti vod v tocích, monitoring znečištovatelů vod, realizace opatření, manipulace na vodních dílech,
- zásobující organizace: návrh a realizace opatření v sítích, náhradní zásobování vodou,

- správci vodních toků: realizace opatření, spolupráce se správcem povodí, vlastníci vodních děl, manipulace na vodních dílech,

- Hasičský záchranný sbor: nouzové zásobování (náhradní úprava vody...),

— Krajská hygienická stanice: hygienický dohled nad kvalitou vody, prevence epidemií v souvislosti se suchem,

- návaznost na krizové rízení - popis konkrétní situace a kritérií, kdy by došlo k prechodu na krizové rízení.

\section{Grafická část}

Grafická část obsahuje zpravidla následující mapy a/nebo schémata:

- mapa území, sídla komisí;

- mapa vodohospodárské soustavy;

- mapa vodovodní sítě

- mapa zdrojů a úpraven vody (včetně rezervních);

- výsledky monitoringu jakosti vod ve zdrojích;

- mapa významných odběratelů vody;

- mapa hlavních znečištovatelů vody.

\section{Prílohy}

Přlohou plánu jsou např::

— odkazy na plány nižších úrovní, popř. významných uživatelů vody:

- dokumentační práce, vyhodnocení epizod sucha včetně vzniklých škod, prričin negativně ovlivňujících zvládání nedostatku vody, účinnosti přijatých opatření a návrhy na úpravu prijímaných opatření:

— související havarijní a krizové plány (popř. odkazy).

\section{Poznámky}

1. Zákon č. 254/2001 Sb., o vodách (vodní zákon), a o změně některých zákonů, ve znění pozdějších předpisů.

2. Zemědělskou prvovýrobou se rozumí chov hospodářských zviřat, pěstování zemědělských plodin, včetně sklizně, výroba mléka, popř. vajec a produkce hospodářských zviŕat před porážkou. 


\section{Poděkování}

Autor děkuje Ing. Petru Březinovi za spolupráci prì prípravě struktury návrhu obsahu plánu a dále členům meziresortní skupiny pro prípravu novely vodního zákona za podnětné pripomínky.

\section{Autor}

Ing. Radek VInas

凶radek.vInas@vuv.cz

Výzkumný ústav vodohospodářský T. G. Masaryka, v. v. i.

\section{THE DROUGHT MANAGEMENT PLAN IN THE CZECH REPUBLIC}

\section{VLNAS, R.}

TGM Water Research Institute, p. r. i.

Keywords: drought - water scarcity - water sources - plan

The paper presents the preparatory phase of the draft of the drought management plan in the Czech Republic in the commenting process. The plan is a basic document of drought protection. It is to be used to coordinate activities in a given area during periods of drought and water scarcity. The plan is a summary of the area's description in terms of water resources and the water supply system, organizational and technical measures needed to prevent or mitigate damage to basic human needs and property, economic activity and the environment related to water demands during the drought.

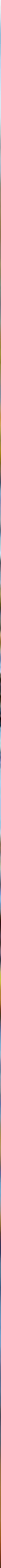

